\title{
Why Yellow Fever Isn't Flattering: A Case Against Racial Fetishes
}

ABSTRACT: Most discussions of racial fetish center on the question of whether it is caused by negative racial stereotypes. In this paper I adopt a different strategy, one that begins with the experiences of those targeted by racial fetish rather than those who possess it; that is, I shift focus away from the origins of racial fetishes to their effects as a social phenomenon in a racially stratified world. I examine the case of preferences for Asian women, also known as 'yellow fever', to argue against the claim that racial fetishes are unobjectionable if they are merely based on personal or aesthetic preference rather than racial stereotypes. I contend that even if this were so, yellow fever would still be morally objectionable because of the disproportionate psychological burdens it places on Asian and AsianAmerican women, along with the role it plays in a pernicious system of racial social meanings.

KEYWORDS: ethics, feminist ethics, feminism, social philosophy, philosophy of race, critical race theory

Race makes a demonstrable difference everywhere: in the workplace and in neighborhoods, in print and on screen, in schools, hospitals, and prisons. We should not be surprised to see the effects of race on even the most intimate spheres of our lives: dating, sex, romance, and marriage. Philosophers have decried the hypocrisy and harms of 'sexual racism' (Coleman 20I I; Thomas I999), that is, the exclusion of others from sexual intimacy on the basis of race, while simultaneously issuing cautions against the naïve view that interracial relationships are guarantors of racial progress (Mills I994; Allen 2000; Sundstrom 2008; for empirical work on sexual racism, see Callander, Holt, and Newman 20I2; Caluya 2008; Raj 20I I; and Riggs 20I3.) These discussions have focused primarily on the moral dimensions of sexually preferring one's own race and whether that analysis differs for dominant and marginalized racial groups. But there has been scarcely any mention of what

This paper has benefited greatly from the interest and feedback of many people, including audiences at the 20I 2 Australian Critical Race and Whiteness Studies Conference, the Humboldt University Symposium Series: Feminist Philosophy and Pornography Conference, the 20I4 Society for Philosophy of Sex and Love Group meeting, the University of Pittsburgh Minorities \& Philosophy (MAP) Reading Group, the Newnham College Pudding Seminar, and the University of Cambridge Women in Philosophy (WiP) speaker series. In addition to those thanked throughout the paper, I am also especially grateful to Elizabeth Anderson, Sarah Buss, Nathaniel Coleman, Kristie Dotson, Miranda Fricker, Raja Halwani, Rae Langton, Ishani Maitra, Patricia Marino, Jennifer Saul, and an anonymous reviewer. 
might be the most visibly racialized sexual phenomenon of all: racial fetish, that is, a person's exclusive or near-exclusive preference for sexual intimacy with others belonging to a specific racial out-group. A paradigm example of racial fetish is what is popularly known as 'yellow fever': a preference for Asian women (and men).

I shall be particularly concerned with the case of yellow fever because it is wellknown and because it best exemplifies the points I wish to make. (For a sense of how yellow fever has long been an object of popular fascination, consider the fact that UrbanDictionary.com, the premier source for user-generated documentation of contemporary slang, boasts no less than 27 definitions of yellow fever, the hit blog 'Stuff White People Like' lists 'Asian women' as \#I I on a list containing over a hundred items, and discussions of yellow fever have regularly appeared in magazine, television, radio, and newspaper articles over the past three decades.) In contrast to sexual racism, the motivations involved in racial fetish are often assumed to be positive or at least harmless. As one woman puts it: 'Asian fetishism has a long history of being brushed off as a compliment, rather than offensive or bigoted. I've been told I ought to be flattered that so many non-Asian men "prefer" Asians and Asian American women' (Chang 2006: 5; see also sMash 2012).

This, then, is my target: the idea that racial fetishism is morally unobjectionable if it is merely an 'aesthetic' or 'personal' preference. In section I, I reconstruct and contextualize an argument for this claim, which I call the Mere Preferences Argument (MPA). In section 2, I raise a concern regarding the most common strategy - to which I am nevertheless highly sympathetic-of rejecting the MPA, which is to argue that such preferences derive from negative racial stereotypes on the part of individuals who have them. In section 3 I adopt a different strategy and begin with the experiences of those targeted by racial fetish rather than those who possess it. I foreground the testimony of Asian and Asian-American (henceforth 'Asian/American') women, whose voices not only remain on the margins of contemporary academic philosophy, but whose unique racial vantage point complicates a racial discourse overwhelmingly centered on the Black/White binary and the oppression of black and brown bodies. I argue that yellow fever is objectionable because of the disproportionate psychological burdens it places on Asian/American women, which derive from the part yellow fever plays in a pernicious system of racial meanings. Finally, in section 4, I consider some objections and conclude by recommending a more forward-looking and structural approach. The key, I argue, is shifting our focus away from the psychological origins of racial fetish in particular individuals to its effects as a social phenomenon in a racially stratified world; in doing so we fortify our critical toolbox with arguments designed for a purportedly 'postracial' world.

\section{The Mere Preferences Argument and Racial Ideology}

Let me begin with a few clarifications and caveats. First of all, I use the term 'racial fetish' advisedly. While I regret and do not intend to invoke the medicalized meaning of 'fetish' as a psychological disorder, this is by far the most common (and pithy) term; moreover, as will become clear, I think this popular use reflects important 
aspects of the social or expressive meaning of such preferences. Second, I group together sex, dating, love, romance, etc. under the metonym of the 'sexual' and for the most part do not discuss their undeniable differences. As sexual attraction is generally assumed to be a necessary condition of love relationships and sexual encounters are understood often to engender love relationships, I think this is not unwarranted. Moreover, encounters with racial fetish typically occur in the context of dating, where it is typically unclear and constantly negotiable whether sex, love, or both are involved. Third, my discussion of yellow fever applies primarily to Asian/American women in the United States though it might generalize to other formerly colonialist countries with Asian immigrant populations. While yellow fever certainly exists (and, indeed, is a powerful economic driver) in Asian countries, the history of colonization and continued postcolonial exploitation raises issues beyond the scope of this paper. ${ }^{\mathrm{I}}$

A common defense of racial fetishes is the claim that they are 'just a preference'. What is usually meant, which I will call the Mere Preferences Argument (MPA), is something like the following:

I. There is nothing morally objectionable about sexual preferences for hair color, eye color, and other nonracialized phenotypic traits.

2. Preferences for racialized physical traits are no different from preferences for nonracialized phenotypic traits. Therefore,

3. 'Mere' preferences for racialized phenotypic traits are not morally objectionable.

To be sure, people may have other reasons for their racialized preferences. But in an age when racial generalizations and stereotypes are widely recognized to be problematic, contemporary defenders of yellow fever (and sexual racism) typically seek to deny that their preferences are anything but purely superficial physical attraction; hence the MPA is my present quarry (Kim 20II: 24I; Prasso 2006: I49; Cohen 2002: I66). Bitna Kim's (20I I: 24I) study of men who prefer Asian women, for example, quotes one: 'Why is it okay, for example, for a man to like and be attracted to blonde girls? Why don't they have a blonde fetish that is looked down upon? So what if a White guy happens to think that Asian women are the most beautiful in the world? Why is that so wrong?' Such beliefs are not limited to nonphilosophers. Raja Halwani (forthcoming), in the most comprehensive and direct treatment of racial fetish to date in the philosophical literature, claims the following (it is important to note, however, that Halwani's discussion is intended to apply only to sexual and not love, marriage, or other intimate relationships):

Just as in the case of [a person who is not sexually attracted to skinny people] we have no good reason to claim that he unfairly discriminates against skinny people, we also have no good reason to claim in the case 
of [a person with yellow fever] that he unfairly discriminates against non-Asians.... If $\mathrm{P}$ is necessary for the proper satisfaction of sexual desire, then in choosing Y's who are $\mathrm{P}, \mathrm{X}$ is not unfairly discriminating against people who are not $\mathrm{P}$. It just so happens that in this case $\mathrm{P}$ is a racial or ethnic property.

Similarly, Charles Mills (I994: I45) claims that 'sexual exoticism per se', which can plausibly be interpreted to mean preferences based on mere phenotype and not stereotype, is ethically unobjectionable so long as there is no deceit involved.

The MPA assumes what Elizabeth Anderson (2010: I 57) refers to as the concept of 'minimal race'. Minimal race is a classification scheme whereby human beings are divided into groups according to what Paul Taylor (20I3) elegantly calls 'bodies and bloodlines' - clusters of phenotypic traits along with geographical ancestrybut without ascriptions of any particular physical, mental, or moral traits to these different groups. By relying on minimal race, advocates of the MPA equate racial fetishes to other preferences for nonracialized phenotypic traits that are widely recognized and found to be morally acceptable. This is evident in the way yellow fever is so frequently justified, as by Kim's (20II) interview subject, as an appreciation of Asian women's physical beauty, i.e., of superficial physical traits and nothing deeper.

I believe the MPA has special currency in a purportedly 'postracial' society where many claim that race no longer matters. Most people do not (openly) endorse classically racist beliefs that different races exhibit different physical, mental, or moral traits. But appeal to minimal race bolsters what sociologist Eduardo BonillaSilva (2OI3) calls a 'color-blind' racial ideology that explains manifestly racialized patterns of outcomes and behavior in terms of nonracial processes, thereby denying the continued existence of racial bias, discrimination, and prejudice. 'Birds of a feather flock together', someone might say, or 'people naturally self-segregate' to account for persistent and obvious racial segregation in housing, friendship, and marriage (Bonilla-Silva 20I3: 76). The MPA supports, and is likely to be motivated by, belief in color-blind ideology.

In light of this, let me point out that the MPA has distinct significance for the case of Asian/American women because of their specific racial location. Sociologists have documented the ways in which Asian/Americans are viewed (however inaccurately) as 'model minorities' or 'honorary whites', with high levels of education, economic achievement, and cultural assimilation (e.g., Chou and Feagin 20I4). Less marked by overtly negative stereotypes, Asian/Americans are often invisible from mainstream narratives of racial discrimination and prejudice faced by more conspicuously disadvantaged groups such as Blacks and Latino/as. Asian/Americans thus represent an especially important test case for the MPA as they are the closest approximation to a group that might be claimed to experience only the effects of minimal race.

One upshot of this proximity to Whiteness is that some Asian/Americans themselves adopt 'a color-blind discourse that prevents them from articulating the racialized nature of certain social experiences... and leaves them unprepared to 
deal with and process racism' (Chou, Lee, and Ho 20I 5: 307). It is unsurprising then that even Asian/American women who profess discomfort with yellow fever may be unable to respond when confronted with the MPA. Kumiko Nemoto's (2006: 34) study of Asian/American women in interracial relationships describes the case of Irene, whose initial response to her boyfriend had been to think: 'Oh no, he likes Asian girls. I didn't like dating guys like that. No, not at all. Growing up Asian, you inevitably meet guys like, “Oh, I love Asian culture”.... I hate that'. Yet, as Nemoto reports:

Irene still was trying to make sense of the fact that Brian had dated only Asian girls and was primarily attracted to Asians. Irene speculated that he liked the physical appearance of Asian/American women and not necessarily Asian cultures or languages: 'That's what his idea of beauty is. So, that's acceptable. I mean it is. He finds a certain type of person attractive.... There's nothing you can do about it logically'. (2006: 34)

Rosalind Chou (2012: 93) quotes another subject who laments, 'It's absolutely ridiculous and I realize that now, but at the time I was just still so young and I hadn't learned about everything yet. I knew it didn't sit right, but I didn't know why'. Arguably, these women experience what Miranda Fricker (2007) calls a 'hermeneutical injustice', that is, an inability to make sense of their own experiences due to marginalization from the collective framework of understanding - in particular, I claim, due to a color-blind ideology that centers White experience and ignores racial dynamics salient from other points of view. In the rest of this paper I shall endeavor to rectify this hermeneutical injustice by validating Asian women's aversion to yellow fever and refuting the idea that there is nothing further to be done (or said) in the face of the MPA.

\section{Yellow Fever and Racial Stereotypes}

One response to the MPA, which I set aside here but take to have considerable merit, is rejecting the first premise. Much empirical research demonstrates that preferences for conventionally attractive phenotypic traits systematically and unjustly disadvantage the life prospects of those who lack them; philosophers have argued that such preferences represent a form of unfair discrimination (Willard I977; Soble I982; Rhode 2010). Moreover, feminists have argued that treating physical attractiveness as a prerequisite for sex and love is oppressive to women, who are already disproportionately judged and valued for how well they conform to feminine beauty ideals rather than for their intellect, ability, and other qualities (Wolf I99I; Bartky I990). These considerations suggest that sexual preferences for (conventionally attractive) phenotypic traits can indeed be objectionable on moral and political grounds.

However, the most obvious response to the MPA is rejecting the second premise. This is indeed the standard move in popular discourse (e.g., Cohen 2002: I66). 
Many Asian/American women detail the racial stereotypes they feel subjected to by men with yellow fever, along with the significant emotional labor required to fulfill, resist, or otherwise negotiate those stereotypes (Chou 2012; Chou, Lee, and Ho 20I 2, 20I 5; Nemoto 2009; Sue et al. 2007). Even worse, stereotypes about Asian women render them particularly vulnerable to sexual harassment and violence by men who target them on that basis (Cho I997; Lee I996; Patel 2009; Park 201 2; Woan 2007). There is thus ample reason to be morally concerned about sexualized racial stereotypes of Asian women.

The response to the MPA here is twofold: first, individuals' racial fetishes always depend on racial stereotypes rather than pure aesthetic features, and second, explicit disavowals of the stereotypes provide no evidence against this fact because the origins of sexual preferences are not usually transparent to those who have them. This amounts to a rejection of the MPA's assumption that preferences can be based on minimal race, asserting instead that they necessarily involve thicker ascriptions of traits to racial groups.

These claims find a great deal of support in scholarly empirical research. Historians, sociologists, psychologists, and literary and film scholars have long documented how White America has viewed Asian/American women in an almost entirely sexual light. This literature demonstrates the mutually reinforcing relationship between material practices, such as federal immigration law, military occupation of East and southeast Asia, war brides, sex tourism, pornography, and mail-order brides, on the one hand, and cultural portrayals of Asian women as the docile, domestic 'Lotus Blossom' or the seductive, treacherous 'Dragon Lady' on the other (e.g., Chan I988; Mazumdar I989; Tajima I989; Uchida I998; Parreñas Shimizu 2007; Woan 2007). In more recent decades, Sumi Cho (I997) and Susan Koshy (2004) argue, the emergence of the Asian 'model minority' stereotypeaccording to which the economic success of (some) Asian immigrant communities has been attributed to a strong work ethic and a culture of valuing educationhas combined with prevailing sexual stereotypes to generate a representation of Asian women as the 'sexual model minority': ideal in their union of sex appeal with family-centered values and a strong work ethic. (It is worth mentioning, as Cho [I997] points out, that this sexual model minority stereotype pits Asian women as a foil against stereotypes of lazy and politically demanding Blacks and against (White) women endorsing feminist values of independence and autonomy.) Some evidence suggests that yellow fever may be motivated by an antifeminist backlash in men who wish to return to traditional gender roles supposedly exemplified by the demure, obedient Asian woman (Cho I997; Fujino 2000; Prasso 2006). As Kim (20II: 237) reports from her study: 'Almost all of those interviewees started with a sentence that negates Asian women as submissive, but, nevertheless, they all mentioned, in one way or another, that Asian women are submissive'.

Moreover, the 'gendering' of races, whereby Asians as a racialized group are stereotyped as feminine, due to their purportedly shy, soft-spoken, submissive racial 'essence', produces what might be called the 'double feminization' of the Asian woman (Arisaka 2000; Galinsky, Hall, and Cuddy 20I3; Johnson, Freeman and Pauker 2OI 2; strikingly, the exact inverse effects are found for Blacks as a racialized 
group, who again, due to their purportedly aggressive 'essence', are stereotyped as masculine). It is this double feminization that increases the sexual capital of Asian women but not that of Asian men, a fact perfectly borne out in the oft-noted greater number of relationships between Asian women and White men compared to the number of Asian men in relationships with White women (e.g., Feliciano, Robnett, and Komaie 2009), in attractiveness ratings that rank Asians highest among women but lowest among men (Lewis 2012), and in the greater representation of Asian women compared to Asian men in popular media (Schug et al. 201 5 ). This crossdisciplinary body of work supports the claim that it would be utterly unrealistic to deny that lengthy exposure to a culture historically saturated with sexualized stereotypes of Asian women contributes to an individual's sexually preferring them, even if that contribution is not obvious or accessible to introspection.

Philosophers typically share this concern about racial stereotypes behind racial fetish. Mills (1994), though accepting of mere sexual exoticism, develops an argument for morally criticizing sexual preferences that involve 'acceptance of a white racist stereotype of beauty' at the expense of non-White racialized phenotypic traits. Presumably, such criticism also applies to sexualized stereotypes of Asian beauty. And although Halwani's (forthcoming) main objective is to argue against attempts to conclude from a person's racial fetish that she is racist or ethically defective, his criteria for assessing racism are primarily concerned with the role of racial stereotypes: we are to check whether the preference contains stereotypes, whether those stereotypes are operative in nonsexual contexts, and whether the person endorses or rejects those stereotypes.

I am wary, however, of leaning too heavily on arguments against racial fetish that appeal to its origins in individuals' (implicit) stereotyping because the nebulous nature of sexual preference cuts both ways. As Halwani (forthcoming) points out, it certainly seems possible (even if unlikely) that some individuals' racial fetishes do not depend in any way on stereotypes; we should not rule out of hand the possibility of individual variation here. Racial fetishes might be based on mere accidents of geography and local demography or even more idiosyncratic personal histories-a first girlfriend or sexual encounter, say. But I don't think that any of this stops racial fetishes from being objectionable or that the targets of yellow fever should not feel bothered when fetishists have their preference for these other reasons. What I am advocating is that we leave aside a preoccupation with the precise origins and nature of yellow fever in particular individuals-which may be impossible to identify with certainty-in order to understand its social effects in a racially segregated and hierarchically ordered world.

\section{The Impact and Social Meaning of Yellow Fever}

Halwani's (forthcoming) conclusion is that some people with racial fetishes are racists while 'others are like people with other sexual preferences-warranting at most a "Who cares?" attitude'. I think, however, that this is too hasty. From the fact that people with racial fetishes are not racists it does not follow that 
there is nothing morally problematic or criticizable about their preferences. For there is another group of affected parties that Halwani fails to consider here: not the people who have racial fetishes, but those targeted by them. It is morally problematic, indeed unjust, when some people suffer disproportionate harms or burdens on the basis of their race and when they are wrongly represented in their sexual capacities. This is one way of understanding some of the wrongs of sexism: women suffer disproportionate sexual harms-objectification, harassment, domestic violence, rape-on account of their gender and are wrongly represented as only valuable in virtue of their sexual capacities, as desiring to be raped, etc. I shall now argue, using the example of yellow fever, that both of these are consequences of racial fetish even when it involves only a concept of minimal race. This gives us alternative (or additional) reasons to reject the second premise of the MPA.

I take Asian/American women's testimony as my starting point for two reasons: first, the additional psychological burden generated by having to cope with yellow fever constitute a form of racial disadvantage in and of itself, and second, the nature of these burdens is an indicator of the negative social meanings expressed by the existence of yellow fever. An overwhelmingly common response from Asian/American women in both popular media and social scientific literature is one of being forced to negotiate constant doubt and suspicion (see e.g., Chang 2006; Chu 2009; and Chou 20I 2; Chou, Lee, and Ho 201 2, 20 I 5 ; Nemoto 2009). Asian/American women consistently report being wary of men with histories of yellow fever, even warning each other against dating venues where they are likely to be targeted for their race (Chou 20I2: 94; Chou, Lee, and Ho 20I2: I I-I 2; 201 5: 309). They describe constant uncertainty over whether others are interested in them for their race. 'Every time someone messages me, I wonder if it's because I'm Asian', a woman states in Marie Claire magazine (Chu 2009). 'I still constantly question if any of the other people I've been involved with or who have found me attractive only felt that way because I'm an Asian woman', a blogger writes (sMash 20I2).

One aspect of this doubt is that targets of yellow fever feel depersonalized or homogenized. 'It always crosses my mind', one reports to the OC Weekly, 'that I'm replaceable' (Chang 2006). While Asian/American women are already subject to sexual objectification as women, racial depersonalization involves a further dimension of objectification that Martha Nussbaum (I995: 257) calls 'fungibility' and in which a person is treated like an object interchangeable with other objects. Importantly, depersonalization can occur merely on the basis of minimal race. For example, the 'own-race bias' and 'out-group homogeneity effect' in which people find it more difficult (visually) to distinguish members of racial out-groups than in-groups is an instance of racial depersonalization that involves no stereotypical content (Park and Rothbart I982, Meissner and Brigham 2001). Siy and Cheryan (2013) show that racial depersonalization is a particularly negative experience in contexts where it matters to be recognized as an individual. As many philosophers have argued, however, love relationships are precisely such a context: love requires just the opposite of fungibility, such that the beloved could not simply be replaced by someone else with similar qualities (e.g., Kraut I987; Kolodny 2003). As Frankfurt 
(2004: 5) writes, love is 'ineluctably particular', or as we might say, it requires being loved for yourself, for who you are. The racial depersonalization inherent in yellow fever threatens Asian/American women with doubts as to whether they are or can be loved as individuals rather than as objects in a category. As Irene, from Nemoto's (2009: 95) study, confesses at one point: 'Sometimes I ask myself if it is because I'm Asian that he's attracted to me because I know that initially, of course, that's what it was. But sometimes, I kind of ask myself, like, if that is the only reason why. I know it is not. But in the back of your head... '. Doubts about yellow fever are painful, and hard to shake.

Another problem is that targets of yellow fever feel otherized. They are separated and held to a different standard. As one of Chou, Lee, and Ho's (201 5:308) subjects puts it: 'I guess I am shallowly complimented, and then I get annoyed because there shouldn't be this discrepancy between "sexy" and "sexy Asian"'. They write: 'The "compliment" to her said something more specific about her race. For example, she is sexy because she is Asian or in spite of it' (Chou, Lee, and Ho 201 5: 308). This otherization is especially acute because Asian/American women-like other women of color-often already suffer from feeling locked out of mainstream White standards of beauty (Mok I998; Chou 2012). And it is an upshot of the mere racial difference involved in minimal race, based on phenotype rather than stereotypes. Asian/American women face a double bind here: their racial difference is either a failure to conform to White standards or only appreciable by alternative or abnormal standards (cf. Raj 20I I on the case of Asian/American men). Connie Chan (1988: 37) describes women who feel 'uncomfortable with the attention given to them as a result of their race or gender', quoting one who says: 'I never felt that I was being complimented for being myself, or the way I looked, but rather for being an Asian female who looked exotic. I stopped trusting any compliments, even ones which were not about my physical appearance'. Another blogs, 'I still feel like I have been objectified, exotified, and hypersexualized because of my race and sometimes I have trouble trusting people who find me attractive because of that' (sMash 20I2). Such doubts are detrimental to a person's (sexual) self-respect and self-esteem.

My contention is that the doubts and suspicions experienced by individual targets of yellow fever constitute unfair harms in themselves that reflect ongoing racial disadvantage, whether or not Asian/American women are actually being homogenized or otherized by men with yellow fever. The limited evidence available from firsthand accounts by men interviewed by Walsh (I990), Weaver (I998), Kim's (20I I) study, Prasso (2006: I4I), and by participants in online yellow-fever communities and mail-order bride services (Prasso 2006: I 47-57, I 57-63), shows that such men often do explain their preference in terms of racial stereotypes, attraction to racialized Asian phenotypes, or other purported racial or cultural differences (e.g., better success with Asian women). Now, it is certainly true that such men-who self-identify with their preference to the point of willingness to be interviewed or to join online communities-might be extreme cases and hence unrepresentative of other men with yellow fever of whom this is not true. But in either case Asian/American women must always contend-at least initially and often long after-with the possibility that attraction might be due to racial fetish 
and that racial fetish might be due to stereotyping. These suspicions may be difficult or impossible to dispel. Chou (201 2: 94) writes:

After giving lectures about the subject of Asian American sexual politics, I have had women come up to me afterward sharing doubt of whether they can ever have white male, and sometimes any nonAsian, partners again. Once they have realized that they were fetishized in the past, it has become almost impossible for them to be clear of any doubt that his interest is free from racial stereotyping. As women of color with increased racial consciousness, they can never be sure.

Suspicions occasioned by yellow fever are of a piece with more general racial doubt, imposed by the way social reality is still ordered according to highly racialized patterns of behavior and outcomes. Particular instances of these patterns may be caused by bias, prejudice, or discrimination-individual or institutional, explicit or implicit, intentional or unintentional—or they may not be. But in all cases, within such a world, people of color must expend valuable psychic and emotional resources on negotiating the problem of constant doubt as they move through it. With every instance of exclusionary behavior, racially inflected comment or joke, negative or indeed positive professional evaluation, people of color must decide whether or not to question it, ignore it, analyze it, challenge it, file a complaint, seek others' opinion and validation, etc.- - all of this takes energy and a toll in ways that White people do not experience (at least not on account of their Whiteness). Negotiating doubt can lead to self-fulfilling prophecies (e.g., Steele, Spencer, and Aronson 2002) and to insecurity about one's abilities, worth, and rationality (e.g., Gildersleeve, Croom, and Vasquez 20II). Having to struggle to justify the rationality of one's own reactions, as I suggested earlier, is a form of hermeneutical injustice because dominant color-blind ideologies suppress explanations based on race even while people continue to experience racialized patterns of treatment. Conversely, even those Asian/American women who ultimately resolve doubts about yellow fever by being unbothered by it or by embracing it or by undergoing the relational work required to establish definitively that their partners are not homogenizing and otherizing them were still saddled, in the first place, with a problem that others are not forced to deal with; very few Asian/American women, if any, can be wholly oblivious to or untouched by it. And it is worth noting that women reporting more positive experiences of yellow fever are often quickly disillusioned, conflicted, or accept the stereotypes themselves (Chou 20I 2: 9, Chou, Lee, and Ho 20I 5: 30, Parreñas Shimizu 2007: 3, Prasso 2006: I40).

By contrast, blondes and brunettes as such have not suffered histories of exploitation, colonization, slavery, persecution, and exclusion on the basis of phenotype. Nor does hair or eye color track categorical differences across all social, economic, and political dimensions of life, including opportunities for health, education, jobs, relationships, legal protections, and more. But race does-in ways that Asian/American women and other people of color experience on a daily basis. Thus while some doubts about fungibility might be an inescapable part of all sexual 
and romantic relationships, whether grounded in physical appearance, personality, or other bases of attraction, racial fetish raises additional and uniquely racialized doubts that require emotionally taxing work to set to rest. The MPA thus fails to recognize the historical and categorical nature of differential treatment based on racialized phenotypes, in virtue of which racial fetishes form only one part of a general pattern and due to which people of color continue to shoulder disproportionate psychic burdens. More generally, advocates of a color-blind ideology fail to understand the ways in which a historically and presently racially ordered world-even if there remained only outwardly 'nonracial' processes-still reproduces racial dynamics that affect people of color in negative ways and hence serve to re-entrench legacies of racial oppression.

The specifically racialized discomfort experienced by individual targets also provides a clue as to the role that yellow fever plays in a larger system of structural racism, that is, in the wrongful representation of Asian women as a group. My point here is this: whether or not some particular case of racial fetish is caused by an individual's harboring racial stereotypes at some level, it inevitably has the effect of reinforcing racial stereotypes. Again, this is true whether or not, as a matter of fact, racialized dating patterns are driven by racial fetishes in reality. Empirical evidence drawn from real-world dating behavior is mixed; some researchers suggest that it is actually Asian women's preferences against Black and Hispanic men that explains the frequency of White men and Asian women in relationships and that White men do not show a preference for Asian women (e.g., Fisman et al. 2008).Others argue that White sexual preferences, which are influenced by racialized and gendered cultural stereotypes, play a larger role (e.g., Feliciano, Robnett, and Komaie 2009). My concern is rather with the social or expressive meaning of yellow fever: with what Laurie Shrage (I992: 44) in a paper on cross-racial prostitution describes as the 'culturally patterned principles of social hierarchy implicit in [men's] selection of prostitutes'. Consider the fact that, although White people are much more likely to date within their race than outside it, there is no term for 'white fever' comparable to 'yellow fever', 'jungle fever', and so on. Choosing to date non-Whites-particularly if you are White-is a deviation that demands explanation. This is why preferences like yellow fever lend themselves so easily to being collectively understood as fetishes. Racialized preferences for a specific out-group possess what Elizabeth Anderson and Richard Pildes (2000) call 'expressive meanings':

Expressive meanings are socially constructed. These meanings are a result of the ways in which actions fit with (or fail to fit with) other meaningful norms and practices in the community.... The expressive meaning of a norm does not inhere in that norm in isolation, but is a product of interpreting the norm in the full context in which it is adopted and implemented. (I 525 )

That is how fetish 'fits' into a White-dominated world and why, for example, popular media always pick up the story and why yellow fever remains a perennial object of public fascination. Defenders of yellow fever who appeal to the MPA try 
to rehabilitate themselves as nondeviant by portraying their preference as nothing more than proper appreciation for Asian women's beauty.

But in the context of a racially ordered world, this move fails. Minimal race is something to be achieved, not assumed. As race does make a difference in every other sphere of life, the expressive meaning of yellow fever is that there is something different about Asian women, something that must be more than mere phenotype. Just as the meanings of words are not wholly up to the individual, such that some words take on an offensive public meaning even if the individual did not intend to offend, so too do racial fetishes in a racially stratified society express racially stereotypical social meanings even if not caused by them and even if individuals with the preference do not endorse them. The more it is known or popularly believed that (White) men have preferences for Asian women, the more difficult it will be for Asian women to be viewed in terms other than as sexual objects. Olivia Espin's (I995: 234) study of immigrant women describes one case as follows: 'Jazmin is keenly aware of the racist stereotypes of Asian women as whores and worries about how she is perceived by strangers when she is affectionate in public with her Caucasian boyfriend. She knows that her race is part of her attractiveness for some white men'. In another interview study by queer and ethnic studies scholar Jeeyeun Lee (I996: II9), a lesbian woman declares: 'I hate seeing Asian women with a white man. I hate it, I just hate it.... I guess it feels especially weird, because every time I see that, I know that's what I'm looked at as [sic]. That's how people see me, as somebody who should be with a white man'. These are direct consequences of yellow fever itself, regardless of its origins. In this way the deviance spreads from the fetishist to its targets. Indeed, women of color more generally (the 'hot Latina', the 'Black ho') are all bypersexualized in this way as possessing essentially deviant sexual natures (Collins 2005; Guillén 201 5; Parreñas Shimizu 2007). It is this expressive social meaning of yellow fever that targets of yellow fever detect and are discomforted by, however inarticulately.

This analysis of expressive meaning also helps explain one of the otherwise puzzling features of yellow fever: if Asian women are so beautiful, why is there such contempt for the men who prefer them? Prasso (2006), Kim (20II), and Chou (20I2) cite evidence that Asian women are perceived to be more accepting of men who are older, unattractive, and socially inept; for example, many of the user-submitted entries on 'yellow fever' featured on UrbanDictionary are openly derisive in listing interests, e.g., anime and manga, associated with 'nerds' and 'geeks' or explicitly associating it with 'male caucasians who haven't yet been laid or haven't gotten up to any level sexually'. This is likely due to the global economic conditions under which many Asian immigrant women of lower-class backgrounds enter marriages with White men. But the result, which conforms to an implicit logic of racial hierarchy, is that White men with yellow fever are often viewed as men unable to date White women. They are, in other words, considered to be 'inferior goods', acceptable to (inferior) Asian women (who may be motivated only by material gain) and who are in this way disadvantageously contrasted with White women despite the positive nature of the stereotype. Again, this is a matter of social meaning and representation, of stigma spreading from fetish to target. The supposed sexual superiority of Asian women ultimately renders them inferior 
as full human beings; they are more completely reduced to having value only as sexual or domestic objects.

Note that particular racial fetishes based on contingent personal histories do not avoid this problem. For it is still a fundamentally racial classification that is doing the work here: why should a person's racialized phenotypes, rather than her personality, hobbies, or even other physical traits be seized upon as the basis for future preferences? But as I have argued, differential treatment on the basis of even minimal race carries with it unavoidably robust racial meanings so long as racialized patterns and structures are in place. Even if racial fetishes do not originate from stereotypes, they are still socially interpreted and made sense of in racially stereotypical ways. Notably, Mills ( 1994: I49) reaches a similar conclusion about Black men marrying White women: even if it were possible for such men to be free of the suspicion that they are motivated by racial self-contempt, the meaning of their actions would be, in his words, 'sending a message to the world that... black women just ain't good enough'. Social psychologist Kay and colleagues (2013) have also showed that exposure even to positive stereotypes makes people more likely to adopt views of racialized groups as biologically and essentially distinct, and makes them subsequently more likely to ascribe negative stereotypes to racialized groups. Finally, another direct effect of yellow fever and other racial fetishes is that they reinforce racialized social structures, such as online dating sites that allow filtering by race, for example, or racial categories of pornography (for discussion, see Robinson 2008). The role of racial fetishes in perpetuating material practices of racial classification and reproducing racial meanings means that racial phenotypes are not like others, and this ultimately renders the second premise of the Mere Preferences Objection false. Yellow fever, by its very nature, is no mere preference.

\section{Concluding Thoughts}

I have argued against the claim that racial fetishes are no different from widely accepted personal or aesthetic preferences for phenotypical traits, such as hair and eye color, and provided empirical evidence to support the claim that they are traceable to hypersexualized racial stereotypes. But I have also argued that racial fetishes are problematic even if they are not caused by racial stereotypes (however unlikely that may be), for at least two reasons. Even without stereotypical content, racial fetishes depersonalize and otherize their targets, subjecting them to disproportionate psychological burdens of doubt, suspicion, and insecurity on account of their race. Moreover, regardless of origin, racial fetishes in a racially stratified society are still interpreted and explained by-and hence expressracially stereotypic social meanings. In this final section, I will consider some objections.

First, one might object that my argument proves too much. What about, say, gender and sexual orientation? Gender has also been the basis for historical and categorical oppression, and sexual preferences based on specific gender certainly contribute to the sexual objectification and other harms suffered by women and LGBTQ individuals. Won't these also count as morally problematic 'fetishes' and 
won't this be a reductio ad absurdum? (This is the precisely the thrust behind several of Halwani's (forthcoming) arguments.) In reply, let me give both a radical and a conservative response. The radical response would be to bite the bullet and concede that sexual preferences based on gender and sexual orientation are indeed morally problematic. But note that this is far from saying something absurd. Feminist philosophers and activists have long seriously considered whether there are moral obligations to be lesbian, bisexual, or pansexual (see, e.g., Trebilcot 2009). And one person's modus ponens is another's modus tollens: legal scholars Ayres and Brown (20II: 30-38) argue by analogy from the moral objectionableness of the racial case to the case of sex and gender, concluding that it is morally better to have sexual preferences that do not discriminate according to sex and gender. They argue, like Thomas (I999), that insofar as sexually intimate relationships are more important than the many other professional and public relationships for which racial or sex discrimination is forbidden, there should be even stronger reason against such discrimination in the intimate realm. Kate Bornstein (I994) has also argued that gender identity should not determine sexual preferences and advocates preferences based instead on preferred sexual activity, for example, top or bottom, dominant or submissive, etc. I believe, moreover, that the enormous variation in historical and cultural standards of sexual attractiveness suggests that humans are capable of such radically widened standards.

My own inclination is to think that there is an important kernel of truth in our resistance to thinking preferences based on gender and sexual orientation are reprehensible: the kernel is that sexual preferences are not in and of themselves morally problematic. In an ideal world, where norms of beauty and attractiveness are such that any given individual stands a chance of being viewed as attractive, or where those norms attach only to traits that could be voluntarily adopted or modified, we might have very few grounds for criticizing sexual preferences. But, I maintain, in an imperfect world that is highly racialized, gendered, and heteronormative, sexual preferences are morally objectionable whenever they are systematized so as to track and reproduce institutions of oppression, even if they glorify rather than stigmatize.

A more conservative response might start from the observation that the targets of preferences based on gender and sexual orientation do not appear to feel the way that the targets of racial fetish do. Most people do not feel depersonalized or otherized by the fact that their attractiveness to others may be contingent on their gender. This indicates something important: the expressive meanings of such preferences are not the same. Insofar as the 'rules of the game' are defined in terms of gender and sexual orientation, distinguishing potential partners on the basis of gender and sexual orientation does not mean that those others are submitted to any differential treatment. ${ }^{2}$ What matters is being able to 'play on equal terms', as it were. As soon as we consider cases where people are presumptively denied such equal footing, the problem of fetish emerges again: preferences for transgender people, people with disabilities, and fat people are similarly regarded by (some of)

2 I am grateful to Nils-Hennes Stear for discussion on this point. 
their targets as 'fetishes', and with just the same sort of discomfort (Emens 2009; Saguy 2002; Solvang 2007; Tompkins 2014).

This brings me to another objection: what about 'progressive' fetishes that work to counteract systems of oppression? Men who prefer Asian men, for instance, are referred to (often derisively) as 'rice queens' in gay communities. ${ }^{3}$ There are similar monikers for 'tranny chasers', 'amputee devotees', and 'fat admirers' (Caluya 2008; Saguy 2002; Solvang 2007; Tompkins 20I4). Ayres and Brown (20II: 34-37) defend an 'antisubordination norm' according to which preferences based on race and gender should be morally evaluated according to whether or not they advance the liberation of historically subordinated groups. Does my account, then, encourage racial fetishes that are antisubordinating?

Not necessarily. To be sure, transgender, disability, and fat activists and scholars have argued for destigmatizing those who find such people attractive because of the implicit assumption that attraction to them must somehow be deviant and abnormal; many self-identified disability and fat fetishists appeal to the MPA in exactly the same fashion as race fetishists (Saguy 2002; Solvang 2007). And in accordance with the vision I outlined above, I fully endorse the widening of beauty norms. However, I think problems of depersonalization and otherizing will be there just the same; as noted, they are already expressed by some transgender, disabled, and fat targets. For individuals who have otherwise been so completely excluded from the game, this may be a price worth paying for the chance to play, and they may embrace fetishization. But I suspect that the appeal of such a trade-off, and hence the acceptability of the fetish, diminishes in proportion to greater progress. (Legal scholar Elizabeth Emens [2009: I343, fn. I 53] observes that the National Association for Fat Advancement previously posted, but has since removed, an official policy in support of 'fat admirers'.) Cross-racial attraction, while perhaps once stigmatized as strongly as transgender, disability, and fat attraction, is so much more accepted and normalized now that the problem of fetish looms far larger than the problem of exclusion from play. My sense, thus, is that such fetishes, even if encountered on the road to progress, are still morally unfortunate.

Finally, one might object on the basis of 'ought implies can': if a sexual preference (for race, gender, etc.) isn't under a person's control, how can it be morally objectionable? Won't we all be forced to deny ourselves love and sex? First, let me be clear that I have not advocated any particular course of action; interracial relationships, like all relationships, must be navigated on a case-by-case basis according to the priorities, values, and trade-offs of the particular individuals involved. Moreover, contra the MPA, racial fetish and its attendant harms are the result of systems of racial meaning and structures of racial disadvantage, not just of flawed individuals. We would thus do better to direct our attention to eliminating the collective existence of racialized sexual stereotypes as expressed through social practice, rather than fixating on the fraught question of whether or not they are 'really' behind some particular individual's preference. (In other words, we can simply set aside the question of whether people's racial fetishes render them racist, 
or ethically defective, since, as I have shown, we can object to these preferences on other grounds.) This is something all of us are implicated in, whether we have fetishes or not. Morality can thus require of all of us, though more urgently in the case of those with racial fetish, that we critically scrutinize our own preferences as well as work toward modifying racially unjust social patterns and structures. Emens (2009: I366), for instance, recommends a dual-level approach to what she calls 'intimate discrimination'.

First, on an individual level, people can engage in 'structured self-inquiry' as an 'ethical endeavor': they can ask themselves, first, what is actually required for the 'essential functions' of being a dating, sexual, romantic, or marriage partner and, second, whether some 'accommodation' could be made such that a social identity, such as race or disability, would no longer preclude a potential partner from performing that function. This kind of critical reflection-undertaken not primarily to assess whether one secretly or implicitly holds stereotypes, but in order to guide future action and growth in response to an unjustified (and, as I have argued, harmful) preference-can set in motion actual behaviors that are not only nonfetishizing but that also have the potential to widen and reshape preferences, for example, expanding and diversifying one's dating pool, social venues, or media consumption. Second, Emens (2009: I367) also stresses the importance of working for solutions at the structural level. For instance, high levels of residential segregation by race decreases the chances of cross-racial interaction and hence opportunities to form intimate relationships, and the local availability of disability accommodations or of the rights attached to the legal status of marriage alters the difficulties of relationships involving members of certain social groups. By working collectively to bring about better social policy, individuals work to alter the structural conditions that serve to support or undermine their sexual preferences; this structural approach addresses the role that yellow fever and other racial fetishes play in a racially stratified social world.

All of this means, I think, that we can and should push back against the standard view that we are not responsible for our sexual preferences because we cannot voluntarily choose or control them by fiat. Instead, we should recognize that we can control whether we choose to take responsibility for our sexual preferences and desires. Feminist, gay, and lesbian philosophers have long argued for the ways in which sexual preferences and identities are not just 'given', fixed, and handed to us on silver platters, but are interpreted, endorsed, or transformed through our capacities for agency and rationality. For instance, William Wilkerson (2009: I00) argues that 'adopting a sexual identity involves a process of acting on a persistent desire, but knowing one's persistent desire involves an act of interpretation that partially constitutes that desire', concluding that sexual identity is partly constituted by choice. Joyce Trebilcot (2009: 34I) has also argued for the view that 'one might discover/create one's own sexuality on the basis of one's feelings and one's politics, on the basis of reasons, on the rational-emotional weighing of all one deems relevant'; taking responsibility for heterosexuality, for instance, consists in 'acknowledging the experiences and feelings she has that are parts of her heterosexuality, and also making the decision to participate or not in the institution of heterosexuality [which] consists not just of sexual activity, but of a myriad of values 
and practices'. My hope is that this paper has contributed to the task of developing ways to take this kind of individual and collective responsibility for sexuality.

ROBIN ZHENG

UNIVERSITY OF CAMBRIDGE

robin.zheng@yale-nus.edu.sg

\section{References}

Allen, A. (2000) 'Interracial Marriage: Folk Ethics in Contemporary Philosophy'. In N. Zack (ed.), Women of Color and Philosophy: A Critical Reader (Malden, MA: Blackwell), I82-205.

Anderson, E. (20I0). The Imperative of Integration. Princeton, NJ: Princeton University Press.

Anderson, E. S., and R. H. Pildes. (2000) 'Expressive Theories of Law: A General Restatement'. University of Pennsylvania Law Review, I48, I 503-75.

Arisaka, Y. (2000). Asian Women: Invisibility, Locations, and Claims to Philosophy. In N. Zack (ed.), Women of Color and Philosophy: A Critical Reader (Hoboken, NJ: Wiley-Blackwell), 209-34.

Ayres, I., and J. G. Brown. (20I I) Straightforward: How to Mobilize Heterosexual Support for Gay Rights. Princeton, NJ: Princeton University Press.

Bartky, S. (1990) Femininity and Domination: Studies in the Phenomenology of Oppression. New York: Routledge.

Bonilla-Silva, E. (2OI3). Racism without Racists: Color-Blind Racism and the Persistence of Racial Inequality in America. Lanham, MD: Rowman \& Littlefield.

Bornstein, K. (I994) Gender Outlaw. New York: Routledge.

Callander, D., M. Holt, and C. E. Newman. (20I2) 'Just a Preference: Racialised Language in the Sex-seeking Profiles of Gay and Bisexual Men.' Culture, Health \& Sexuality, I4, I049-63.

Caluya, G. (2008) “The Rice Steamer': Race, Desire and Affect in Sydney's Gay Scene.' Australian Geographer, 39, 283-92.

Chan, C. S. (I988) 'Asian-American Women: Psychological Responses to Sexual Exploitation and Cultural Stereotypes.' Women \& Therapy, 6, 33-38.

Chang, V. (2006) 'Yellow Fever.' OC Weekly. Available at: http://www.ocweekly.com/2006I I-2/news/yellowfever/. Accessed I6 December 20I 5.

Cho, S. K. (1997) 'Converging Stereotypes in Racialized Sexual Harassment: Where the Model Minority Meets Suzie Wong.' Journal of Gender, Race and Justice, I, I78-2I I.

Chou, R. S. (20I2). Asian American Sexual Politics: The Construction of Race, Gender, and Sexuality. Lanham, MD: Rowman \& Littlefield.

Chou, R., and J. R. Feagin. (20I4). The Myth of the Model Minority: Asian Americans Facing Racism, 2 d ed. St. Paul, MN: Paradigm Publishers.

Chou, R., K. Lee, and S. Ho. (20I2). 'The White Habitus and Hegemonic Masculinity at the Elite Southern University: Asian Americans and the Need for Intersectional Analysis'. Sociation Today, Iо.

Chou, R., K. Lee, and S. Ho. (20I 5). 'Love Is (Color)blind: Asian Americans and White Institutional Space at the Elite University'. Sociology of Race and Ethnicity, I, 302-I6.

Chu, Y. (2009) 'The New Trophy Wives: Asian Women'. Marie Claire. Available at: http://www.marieclaire.com/sex- love/advice/asian-trophy-wife. Accessed I 6 December 2015.

Cohen, R. (2002) The Good, the Bad \& the Difference: How to Tell the Right from Wrong in Everyday Situations. New York: Doubleday.

Coleman, N. (2OII) 'What? What? In the (Black) Butt'. APA Newsletter on Philosophy and Lesbian, Gay, Bisexual, and Transgender Issues, I I, I 2-I 5.

Collins, Patricia Hill. (2005) Black Sexual Politics: African Americans, Gender, and the New Racism. New York: Routledge. 
Emens, E. F. (2009) 'Intimate Discrimination: The State's Role in the Accidents of Sex and Love.' Harvard Law Review, I22, I308-1402.

Espin, O. M. (I995). “"Race”, Racism, and Sexuality in the Life Narratives of Immigrant Women'. Feminism \& Psychology, 5, 223-38.

Feliciano, C., B. Robnett, and G. Komaie. (2009) 'Gendered Racial Exclusion among White Internet Daters'. Social Science Research, 38, 39-54.

Fisman, R., S. I. Sheena, K. Emir, and I. Simonson. (2008). 'Racial Preferences in Dating.' Review of Economic Studies, 75, II 7-32.

Frankfurt, H. (2004) The Reasons of Love. Princeton: Princeton University Press.

Fricker, M. (2007) Epistemic Injustice: Power and the Ethics of Knowing. New York: Oxford University Press.

Fujino, D. (2000) 'Structural and Individual Influences Affecting Racialized Dating Relationships'. In J. Chin (ed.), Relationships Among Asian American Women (Washington, D.C.: American Psychological Association), I8 I-209.

Galinsky, A., E. Hall, and A. Cuddy. (20I3) ‘Gendered Races: Implications for Interracial Marriage, Leadership Selection, and Athletic Participation'. Psychological Science, 24, 498-506.

Gildersleeve, R. E., N. N. Croom, and P. L. Vasquez. (20I I) “"Am I going crazy?!”: A Critical Race Analysis of Doctoral Education'. Equity \& Excellence in Education, 44, 93-I I 4.

Guillén, J. C. (2015) 'Imposed Hispanicity: How the Imposition of Racialized and Gendered Identities in Texas Affects Mexican Women in Romantic Relationships with White Men'. Societies, $5,778-806$.

Halwani, R. (Forthcoming, manuscript as of 9 July 20r6) 'Racial Sexual Desires.' In A. Noble, R. Halwani, and S. Hoffman (eds.), The Philosophy of Sex: Contemporary Readings, 7 th ed. (Washington, D.C.: Rowman and Littlefield).

Johnson, K., J. Freeman, and K. Pauker. (20I2) 'Race is Gendered: How Covarying Phenotypes and Stereotypes Bias Sex Categorization'. Journal of Personality and Social Psychology, IO2, II 6-3I.

Kay, A., M. Day, M. Zanna, and A. Nussbaum. (2013) 'The Insidious (and Ironic) Effects of Positive Stereotypes'. Journal of Experimental Social Psychology, 49, 287-91.

Kim, B. (20II) 'Asian Female and Caucasian Male Couples: Exploring the Attraction'. Pastoral Psychology, 60, 233-44.

Kolodny, N. (2003) 'Love as Valuing a Relationship'. Philosophical Review, I I2, I 35-89.

Koshy, S. (2004). Sexual Naturalization: Asian Americans and Miscegenation. Palo Alto, CA: Stanford University Press.

Kraut, R. (1987) 'Love De Re” Midwest Studies in Philosophy, I0, 4I3-30.

Lee, J. (I996) 'Why Suzie Wong Is Not a Lesbian: Asian/American Lesbian and Bisexual Women and Femme/Butch/Gender Identities'. In B. Beemyn and M. Eliason (eds.), Queer Studies: A Lesbian, Gay, Bisexual, \& Transgender Anthology (New York: NYU Press), I I 5-32.

Lewis, M. (2OI 2) 'A Facial Attractiveness Account of Gender Asymmetries in Interracial Marriage'. $P L O S$ ONE, 7, 3 I 703 .

Mazumdar, S. (1989) 'General Introduction: A Woman-Centered Perspective on Asian American History'. In Asian Women United of California (ed.), Making Waves: An Anthology of Writings By and About Asian American Women (Boston: Beacon Press), 25-30.

Meissner, C. A., and J. C. Brigham. (200I). 'Thirty Years of Investigating the Own-race Bias in Memory for Faces: A Meta-analytic Review'. Psychology, Public Policy, and Law, 7, 3-35.

Mills, C. W. ( I994) 'Do Black Men Have a Moral Duty to Marry Black Women?' Journal of Social Philosophy, 25, I3 I-53.

Mok, T. (1998) 'Asian Americans and Standards of Attractiveness: What's in the Eye of the Beholder?' Cultural Diversity and Mental Health, 4, I-I 8.

Nemoto, K. (2006) 'Intimacy, Desire, and the Construction of Self in Relationships between Asian American Women and White American Men'. Journal of Asian American Studies, 9, 27-54.

Nemoto, K. (2009) Racing Romance: Love, Power, and Desire Among Asian American/White Couples. New Brunswick: Rutgers University Press.

Nussbaum, M. C. (I995). 'Objectification'. Philosophy \& Public Affairs, 24, 249-9I. 
Park, H. (20I2) 'Interracial Violence, Western Racialized Masculinities, and the Geopolitics of Violence Against Women'. Social \& Legal Studies, 2I, 49 I-509.

Park, B., and M. Rothbart. (1982). 'Perception of Out-group Homogeneity and Levels of Social Categorization: Memory for the Subordinate Attributes of In-group and Out-group Members'. Journal of Personality and Social Psychology, 42, 105 I-68.

Parreñas Shimizu, C. (2007) The Hypersexuality of Race: Performing Asian/American Women on Screen and Scene. Durham: Duke University Press.

Patel, N. (2009) 'Racialized Sexism in the Lives of Asian American Women'. In C. Raghavan, A. E. Edwards, and K. M. Vaz (eds.), Benefiting by Design: Women of Color in Feminist Psychological Research (Cambridge Scholars Publisher), i 16-28.

Prasso, S. (2006) The Asian Mystique. New York: Public Affairs.

Raj, S. (20 I I) 'Grinding Bodies: Racial and Affective Economies of Online Queer Desire'. Critical Race and Whiteness Studies, 7.

Rhode, D. L. (2010) The Beauty Bias: The Injustice of Appearance in Life and Law. New York: Oxford University Press.

Riggs, D. W. (2013) 'Anti-Asian Sentiment Amongst a Sample of White Australian Men on Gaydar'. Sex Roles, 68, 768-78.

Robinson, R. K. (2008) 'Structural Dimensions of Romantic Preferences'. Fordham Law Review, $76,2787-28$ I 9 .

Saguy, A. C. (2002) 'Sex, Inequality, and Ethnography: Response to Erich Goode'. Qualitative Sociology, 25, 549-56.

Schug, J., N. P. Alt, P. S. Lu, M. Gosin, and J. L. Fay. (2015) 'Gendered Race in Mass Media: Invisibility of Asian Men and Black Women in Popular Magazines'. Psychology of Popular Media Culture. Available at: doi: http://dx.doi.org/I0.1037/ppmoo00096.

Shrage, L. (I992) 'Is Sexual Desire Raced?: The Social Meaning of Interracial Prostitution'. Journal of Social Philosophy, 23, 42-5I.

Siy, J. O., and S. Cheryan. (2013) 'When Compliments Fail to Flatter: American Individualism and responses to Positive Stereotypes'. Journal of Personality and Social Psychology, 104, 87-102.

sMash, L. (2012) 'Yellow Fever: Dating as an Asian Woman'. Persephone Magazine. Available at: http://persephonemagazine.com/20 I2/or/yellow-fever-dating-as-an-asian-woman/. Accessed I6 Dec. 2015.

Soble, A. (1982) 'Physical Attractiveness and Unfair Discrimination'. International Journal of Applied Philosophy, I, 37-64.

Solvang, P. (2007) 'The Amputee Body Desired: Beauty Destabilized? Disability Re-valued?' Sexuality and Disability, $25,5 \mathrm{I}-64$.

Steele, C. M., S. J. Spencer, and J. Aronson. (2002) 'Contending with Group Image: The Psychology of Stereotype and Social Identity Threat'. Advances in Experimental Social Psychology, 34, 379-440.

Sue, D. W., J. Bucceri, A. I. Lin, K. L. Nadal, and G. C. Torino. (2007). 'Racial Microaggressions and the Asian American Experience'. Cultural Diversity and Ethnic Minority Psychology, I3, $72-8 \mathrm{I}$.

Sundstrom, R. (2008) 'Racism and the Political Romance of the Browning of America'. Philosophy. Paper, 47. Available at: http://repository.usfca.edu/phil/47. Accessed I6 Dec. 20 I 5.

Tajima, R. (1989) 'Lotus Blossoms Don't Bleed: Images of Asian Women'. In Asian Women United of California (ed.), Making Waves: An Anthology of Writings by and about Asian American Women (Boston: Beacon Press), 308-I 8.

Taylor, P. C. (20I3). Race: A Philosophical Introduction. Cambridge, UK: Polity Press.

Thomas, L. M. (I999) 'Split-level Equality: Mixing Love and Equality'. In S. E. Babbitt and S. Campbell (eds.), Racism and Philosophy (Ithaca: Cornell University Press), I 89-20I.

Tompkins, A. B. (20I4) “"There's No Chasing Involved”: Cis/Trans Relationships, “Tranny Chasers," and the Future of a Sex-Positive Trans Politics'. Journal of Homosexuality, 6I, 766-80.

Trebilcot, J. (2009) 'Taking Responsibility for Sexuality'. In R. Baker, K. Wininger, and F. Elliston (eds.), Philosophy and Sex, 4 th ed. (Amherst, New York: Prometheus Books), 337-45. 
Uchida, A. (1998) 'The Orientalization of Asian Women in America'. Women's Studies International Forum, 2I, I6I-74.

Walsh, J. (I990) 'Asian Women, Caucasian Men'. San Francisco Examiner/Chronicle Image, I II6.

Weaver, C. (1998) 'Tiny, Flat-chested, and Hairless!'. Salon. Available at: http://www.salon. com/I998/05/06/weav_22/. Accessed I6 Dec. 2015.

Wilkerson, W. S. (2009). 'Is it a Choice? Sexual Orientation as Interpretation'. Journal of Social Philosophy, 40, 97-II6.

Willard, L. D. (I977) 'Aesthetic Discrimination Against Persons'. Dialogue: Canadian Philosophical Review, 16, 676-92.

Woan, S. (2007) 'White Sexual Imperialism: A Theory of Asian Feminist Jurisprudence'. Washington \& Lee Journal of Civil Rights \& Social Justice, I4, 275.

Wolf, N. (I99I) The Beauty Myth. New York: Random House. 